\title{
Association of PICK1 and BDNF variations with increased risk of methamphetamine dependence among Iranian population: a case- control study
}

\author{
Amir Tajbakhsh ${ }^{1,2}$, Maliheh Alimardani ${ }^{2}$, Mahla Asghari ${ }^{2 \dagger}$, Soheila Abedini ${ }^{2 \dagger}$, Sohrab Saghafi Khadem ${ }^{3 \dagger}$, \\ Abolfazl Nesaei Bajestani ${ }^{4}$, Forough Alipoor ${ }^{5}$, Maryam Alidoust ${ }^{2}$, Amir Savardashtaki ${ }^{6,7}$, Peyman Hashemian ${ }^{8, *^{*}}$ \\ and Alireza Pasdar $2,10^{*}$ (D)
}

\begin{abstract}
Background: Genetic factors play an important role in susceptibility to methamphetamine dependency. In this line, protein that interact with C-kinase-1 (PICK1) and brain-derived neurotrophic factor (BDNF) genes are linked to methamphetamine dependence (substance use disorder). Thus, in a case-control study, we investigated the association between polymorphisms of PICK1 and BDNF genes and methamphetamine dependence in an Iranian population.

Methods: Total of 235 cases and 204 controls were recruited in a period between 2015 to 2018. The PICK1-rs713729, -rs2076369 and BDNF-rs6265 genotypes were determined via ARMS-PCR assay. Statistical analysis was performed, using SPSS 20.0, PHASE 2.1.1 program as well as SNP Analyzer 2.0.

Results: In the present study, two polymorphisms including PICK1-rs713729 (OR 1.38 (Cl 1.08-1.52; $P_{\text {-value }} 0.004$ ) in multiplicative and dominant models, and PICK1-rs2076369 (OR 1.31 (Cl 1.10-1.56; $P_{\text {-value }} 0.002$ ) in multiplicative, dominant and co-dominant models were associated with the risk of methamphetamine abuse. Moreover, haplotype analysis showed a significant association of haplotype AG (OR 2.50 (Cl 1.50-4.16; $P_{-}$value 0.0002$)$ in dominant, recessive and co-dominant models, and haplotype TT (OR 0.67 (Cl 0.50-0.91; $\left.P_{- \text {value }} 0.009\right)$ in dominant and co-dominant models with the risk of methamphetamine abuse. None of the polymorphisms in this study had a high level of linkage disequilibrium.
\end{abstract}

Conclusion: Our findings indicate that the PICK1 gene polymorphism might affect the risk of methamphetamine dependency in our population.

Keywords: Addiction, Drug abuse, Substance dependence, Substance use disorder (SUD), Dopamine pathway, Glutamate pathway, Variations, And polymorphisms

*Correspondence: HashemianP@mums.ac.ir; PasdarA@mums.ac.ir †Mahla Asghari, Soheila Abedini and Sohrab Saghafi Khadem contributed equally as the third author

${ }^{2}$ Department of Medical Genetics and Molecular Medicine, Faculty of Medicine, Mashhad University of Medical Sciences, Mashhad, Iran

${ }^{8}$ Medical Genetics Research Centre, Mashhad University of Medical Sciences, Mashhad, Iran

Full list of author information is available at the end of the article

\section{Background}

Methamphetamine is the most extensively abused illegal drug and this is a growing global problem [1-3]. Many changes occur in the human brain as a result of methamphetamine abuse [4]. Methamphetamine leads to the release of synaptic dopamine, which might be a reason for the increased addiction [4]. In this context, 
methamphetamine can have neurotoxic effects on dopaminergic neurons and also contribute to changes in another neurotransmitter system, particularly glutamate $[5,6]$. Glutamate-mediated excitotoxicity is the major mechanism by which methamphetamine damages the central nervous system (CNS) [7, 8]. Moreover, the primary target of methamphetamine is the dopamine transporters, which remove dopamine from the extracellular space at the synapse and controls dopamine signals [9]. The function and surface availability of the dopamine transporter are regulated via different cellular mechanisms $[10,11]$. Additionally, it was stated that the density of dopamine transporter is low in the caudate/putamen of methamphetamine abusers, suggesting that the longterm use of methamphetamine results in damage to dopaminergic neurons $[12,13]$.

Several factors are involved in methamphetamine abuse. In this line, genetic factors play an important role in susceptibility to the use of methamphetamine [1-3]. The dopamine transporter, polymorphisms have been shown to be a risk factor for prognosis of prolonged-type methamphetamine psychosis, such as a single nucleotide polymorphism (SNP) [14, 15]. Moreover, in a systematic review, Bousman et al. showed that several genes are involved in methamphetamine-related disorders. It has been shown that three genes including catechol-Omethyltransferase (COMT), gamma-aminobutyric acid type A receptor subunit alpha1 (GABRA1) and dopamine receptor D4 (DRD4), nine genes including, brainderived neurotrophic factor $(B D N F)$, arrestin beta 2 (ARRB2), cytochrome P450 2D6 (CYP2D6), glutathione S-transferase mu 1 (GSTM1), glycine transporter-1 (GLYT1), glutathione S-transferase P1 (GSTP1), solute carrier family 22 member 3 (SLC22A3), prodynorphin $(P D Y N)$, and protein interacting with $\mathrm{C}$ kinase (PICK1), two genes including gamma-aminobutyric acid receptor subunit gamma-2 (GABRG2) and v-akt murine thymoma viral oncogene homolog 1 ( $A K T 1$ ) seem to be associated with methamphetamine abuse or dependence in Japanese and Han-Chinese populations [15]. It is indicated that the genetic epidemiology of methamphetamine abuse is very complex. There is an association between PICK1 gene and drug addiction, such as methamphetamine abuse [16]. In this respect, the PICK1 gene is mapped to chromosome 22q13.1 [17]. Interestingly, PICK1 interacts with dopamine transporter, which leads to the clustering of dopamine transporter on the cell surface and subsequently the improvement of dopamine transporter uptake activity $[16,18]$.

Furthermore, BDNF-rs6265 is a functional SNP, which affects drug dependency [19]. BDNF gene is mapped to chromosome $11 p$. It was found that BDNFrs6265 (Val66Met) SNP is linked to susceptibility to methamphetamine dependence in a Thai and Malaysian population [20-22]. In this respect, BDNF proteins are involved in the regulation of synaptic transmission as well as the process underlying substance use disorder (SUD) [23]. BDNF was shown to support the survival and protection of dopaminergic neurons following methamphetamine administration in mice [6]. The functional effects of SNPs, which are linked to SUD, are often unclear; hence, more investigations are required on different populations to define how these variants influence gene expression and function. In this case, worldwide participatory attempts are warranted to promote the accessibility of large population-based datasets/samples and to increase the feasibility of genetic association studies [15]. On the other hand, a systematic review by Alam-MehrJerdi et al. indicated that the state of methamphetamine abuse requires further research on the epidemiology and health-related implications in Iran [24]. Therefore, we aimed to investigate the association between PICK1 and $B D N F$ main SNPs and methamphetamine dependence (substance use disorder (SUD)) in a cohort of Iranian individuals.

\section{Methods}

\section{The aim, design and setting of the study}

This case-control study involved 235 cases (with methamphetamine dependence (SUD)) and 204 gendermatched controls (healthy individuals). In our study, SUD was recognized by the 11 criteria. The 11 criteria are divided into four categories of behavior, such as impaired control, social impairment, risky use and pharmacological indicators (tolerance and withdrawal) related to the substance use (Table 1) $[25,26]$.

The PICK1-rs713729, PICK1-rs2076369 and BDNFrs6265 genotypes were analyzed by amplification refractory mutation system-polymerase chain reaction (ARMS-PCR) assay. Subsequently, statistical analysis was performed, using SPSS 20.0 (IBM Inc., Chicago, IL, USA), PHASE 2.1.1 program as well as SNP Analyzer 2.0.

The characteristics of participants Study population and clinical data

This study was performed in accordance with the Declaration of Helsinki (1964) and its subsequent amendments. Moreover, approval was obtained from the local Ethics committee of Mashhad University of Medical Sciences (IR.MUMS.fm.REC.1394.421), 439 blood samples were collected from 204 controls and 235 cases from Mashhad, Iran from 2015 to 2018. After explaining the study objectives, a written informed consent was obtained from all participants. A questionnaire was used to collect demographic and other essential information from all participants (Table 2). The selection procedure included confirmed urine test (addiction test) and 
Table 1 Criteria for substance use disorders (SUD)

\begin{tabular}{|c|c|c|}
\hline Num & Categories of behaviour & Criteria for Substance Use Disorders (SUD)* \\
\hline 1 & Impaired control & Used larger amounts or longer: Taking the drug in greater quantities or over prolonged periods of time \\
\hline 2 & & $\begin{array}{l}\text { Repeated attempts to control use and/or quit: Wanting to cut or avoid using the substance, but they haven't been } \\
\text { successful }\end{array}$ \\
\hline 3 & & Much time spent using: Spending a lot of time to get, using, or recover from substance using \\
\hline 4 & & Craving: Cravings and encourages the substance to be used \\
\hline 5 & Social impairment & $\begin{array}{l}\text { Activities given up to use: Not able to do what you can do at home, at work, or at school that you once liked because } \\
\text { of substance use }\end{array}$ \\
\hline 6 & & $\begin{array}{l}\text { Social or interpersonal problems related to use: Continuing to use, even though it creates issues in your relationships } \\
\text { or conflicts with others }\end{array}$ \\
\hline 7 & & $\begin{array}{l}\text { Neglected major roles to use: Giving up and refusing to perform significant social, occupational or recreational func- } \\
\text { tions as a result of substance use }\end{array}$ \\
\hline 8 & Risky use & Hazardous use: Using substances again and again, including though you or others are in danger \\
\hline 9 & & $\begin{array}{l}\text { Social or interpersonal problems related to use: Continuing to use, even though you know that you have a physical or } \\
\text { psychological condition which may have been triggered or exacerbated by the substance }\end{array}$ \\
\hline 10 & Pharmacological indicators & Tolerance: Need more substance to have the effect you like \\
\hline 11 & & $\begin{array}{l}\text { Withdrawal: Development of withdrawal symptoms and signs of withdrawal, which can be eased by taking more of } \\
\text { the substance }\end{array}$ \\
\hline
\end{tabular}

*In the present study, substance use disorders (SUD) is recognized by these 11 criteria

Table 2 Demographic and clinical characteristics of controls and methamphetamine dependence (SUD)

\begin{tabular}{|c|c|c|c|c|}
\hline Variable & & Controls & $\begin{array}{l}\text { Methamphetamine dependence } \\
\text { (SUD) }\end{array}$ & $P_{\text {-value }}{ }^{*}$ \\
\hline \multirow[t]{2}{*}{ Gender } & Female & $38.9 \%$ & $35.7 \%$ & $P<0.001$ \\
\hline & Male & $68.1 \%$ & $64.3 \%$ & \\
\hline Age (SD) & & $31.96(8.44 \pm 0.58)$ & $38.91(9.11 \pm 0.68)$ & $P=0.423$ \\
\hline \multirow[t]{5}{*}{ Marriage status } & Married & $56.7 \%$ & $43.4 \%$ & $P<0.001$ \\
\hline & Separated & - & $11.6 \%$ & \\
\hline & Widow & - & $4.2 \%$ & \\
\hline & Divorced & $1.1 \%$ & $20.6 \%$ & \\
\hline & Single & $42.1 \%$ & $20.1 \%$ & \\
\hline
\end{tabular}

*Significant $\mathrm{P}_{\text {-value }}<0.05$. SD: Standard deviation

also the availability of complete patient's follow-up data. Moreover, healthy participants, individually matched on age, were recruited from the Health Examination Centre who were receiving routine medical examinations.

\section{Description of materials}

\section{Blood collection and DNA extraction}

In order to extract the DNA, approximately 10 millilitres $(\mathrm{ml})$ of peripheral blood was obtained from all participants and immediately subdivided into tubes containing sterile ethylene diamine tetra acetic acid (EDTA) [27]. DNA extraction from whole blood was extracted using salting-out technique. Then, the extracted DNA was quantified by the ratio of absorbance at $260 \mathrm{~nm}(\mathrm{~nm})$ and $280 \mathrm{~nm}\left(\mathrm{~A}_{260 / 280}\right)$ via BioTek $^{\mathrm{TM}}$ Epoch $^{\mathrm{TM}}$ Microplate
Spectrophotometer (Winooski, VT, USA,) as well as via gel electrophoresis and finally stored at $-20^{\circ} \mathrm{C}$ until used.

Target single nucleotide polymorphisms (SNPs)

determinations (Marker selection)

In this study, the SNPs were selected using available SNPs databases and published articles. Such articles examined intron and exon SNPs, which might alter the affinity of PICK1-rs713729, PICK1-rs2076369 and BDNF-rs6265 to methamphetamine dependence (SUD) (Table 3). Moreover, potential functional SNPs were included in order to meet the following criteria: minor allele frequency $(\mathrm{MAF})>0.05(5 \%)$, heterozygosity $>0.15(15 \%)$ and also validated SNPs in articles and databases. Furthermore, in order to inhibit redundancy in SNPs genotyping, SNPs that are not located in strong linkage disequilibrium (LD) were chosen. 
Table 3 Characteristics of the investigated polymorphisms in this study

\begin{tabular}{|c|c|c|c|c|c|c|c|c|}
\hline Rs number & Gene & Protein & Position & $\begin{array}{l}\text { Exon/ } \\
\text { Intron }\end{array}$ & $\begin{array}{l}\text { Variant } \\
\text { length }\end{array}$ & Allele & Function & $\begin{array}{l}\text { Haplotype } \\
\text { distance } \\
\text { (bp) }\end{array}$ \\
\hline rs713729 & PICK1 & Non-coding & $22: 38,059,462$ & Intron 3 & 1 & $\mathrm{~T}>\mathrm{A}$ & Intron variant & 8183 \\
\hline rs2076369 & PICK1 & Non-coding & $22: 38,067,645$ & Intron 4 & 1 & $T>G$ & Intron variant & \\
\hline rs6265 & $B D N F$ & $\begin{array}{l}\text { NP_001137277.1:p. } \\
\text { Val66Met }\end{array}$ & $11: 27,658,369$ & Exon 4 & 1 & $C>T$ & Missense & - \\
\hline
\end{tabular}

PICK1: Protein that interact with C-kinase-1; BDNF: Brain-derived neurotrophic factor; Val66Met (also called rs6265): Met: Methionine and Val: Valine; METH: Methamphetamine; bp: Base pairs

\section{Genotyping}

To determine the genotype frequency of PICK1-rs713729, PICK1-rs2076369 and BDNF-rs6265 an ARMS-PCR method was used. Specific primers for PCR amplification were designed via web tools, such as Primer1 and also WASP (web-based allele-specific primer designing tool) [28].

PCR amplifications for PICK1-rs713729, PICK1rs2076369 and BDNF-rs6265 were conducted in a $10-15 \mu \mathrm{l}(\mu \mathrm{l})$ volume per reaction, containing $3 \mu \mathrm{l}$ Taq $2 \times$ master mix (Ampliqon, Germany), $10 \mu \mathrm{M}$ of each primer and 100 nanogram (ng) DNA. Moreover, the specific primers used to detect PICK1-rs713729, PICK1rs2076369 and BDNF-rs6265 SNPs are listed in Table 4. For PICK1-rs2076369, we also used betaine (Ampliqon, Germany) as an enhancer in PCR.

The ARMS-PCRs condition for each primer is as follows, Table 5. In general, initial denaturation at temperature $94{ }^{\circ} \mathrm{C}$ for five minutes, then 35 cycles including denaturation at $94{ }^{\circ} \mathrm{C}$ for $25 \mathrm{~s}$, annealing at alternative ${ }^{\circ} \mathrm{C}$ for $25 \mathrm{~s}$ (based on each primer), an elongation at $72{ }^{\circ} \mathrm{C}$ for
$30 \mathrm{~s}$ followed by $72{ }^{\circ} \mathrm{C}$ for seven minutes as the final elongation step (Table 5).

Absence or presence of mutant or normal PCR products were detected via gel electrophoresis in 3\% agarose gel by ultraviolet (UV) trans illuminator (Gel Doc; U:Genius).

\section{Statistical analysis}

A Hardy-Weinberg equilibrium (HWE) method was used to evaluate the differences in data for statistical significance. HWE assumption was investigated by the Pearson $\chi^{2}$ distribution with 1 degree of freedom. Allele and genotype frequencies were calculated, and the differences between groups were evaluated by Chi-squared tests. Then, the association between methamphetamine, risk factors and alleles/genotypes was evaluated by binary logistic regression, estimating Odds ratios (ORs) and also 95\% confidence intervals (CIs). Three logistic regression models were used to analyse the SNPs, using different genetic models (additive, dominant, and recessive). For the analysis of SNP-SNP interactions, an adjusted logistic regression model was used to estimate the multiplicative

Table 4 Primer sequences used for genotyping in ARMS-PCR

\begin{tabular}{|c|c|c|c|c|}
\hline SNPs & Primers & Sequences & Primer Length (bp) & $\begin{array}{l}\text { PCR } \\
\text { products } \\
\text { (bp) }\end{array}$ \\
\hline \multirow[t]{4}{*}{ rs6265 } & $\mathrm{FO}$ & CTACAGTTCCACCAGGTGAGAAGAGTG & 27 & 400 \\
\hline & $\mathrm{RO}$ & ATGGACATGTTTGCAGCATCTAGGTA & 26 & \\
\hline & $\mathrm{FI}(\mathrm{c})$ & TGGTCCTCATCCAACAGCTCTTCTATAAC & 29 & 253 \\
\hline & $R I(t)$ & TTGGCTGACACTTTCGAACcCA & 22 & 201 \\
\hline \multirow[t]{4}{*}{ rs713729 } & $\mathrm{FO}$ & CTTTCTAGCGGAATCCCGACTGTG & 24 & 407 \\
\hline & $\mathrm{RO}$ & CAGTGAAAAAGCAAACCAGGACACTG & 26 & \\
\hline & $\mathrm{Fl}(\mathrm{a})$ & CTTCTCATTCTTGAGGTCTGACCCACA & 27 & 196 \\
\hline & $\mathrm{RI}(\mathrm{t})$ & AGGTGGTCAGAAAGCCCCTCAGA & 23 & 265 \\
\hline \multirow[t]{4}{*}{ rs2076369 } & $\mathrm{FO}$ & CATGTTGCCCAAGCTGGTCTCAAACTC & 27 & 299 \\
\hline & $\mathrm{RO}$ & CTGGACACCCGTAACTGCTCTGACC & 35 & \\
\hline & $\mathrm{Fl}(\mathrm{g})$ & AGGAGTCTCAGTCCAGAACAGTCTTGACG & 29 & 191 \\
\hline & $\mathrm{RI}(\mathrm{t})$ & СTCCACACCCTGAGCCCCTTCTCA & 24 & 165 \\
\hline
\end{tabular}

Expected product size in bps depending on the SNPs. FO: Forward outer primer; FI: Forward inner primer; RI: Reverse inner primer; RO: Reverse outer primer; bp: Base pairs; ARMS-PCR: Amplification refractory mutation system-polymerase chain reaction; SNP: Single nucleotide polymorphism 
Table 5 The ARMS-PCRs condition for targeted SNPs

\begin{tabular}{|c|c|c|c|c|c|c|c|c|c|c|c|}
\hline \multirow[t]{3}{*}{ SNPs } & \multirow[t]{3}{*}{ Primers } & \multicolumn{2}{|c|}{ First Denaturation } & \multicolumn{6}{|c|}{35 cycles } & \multicolumn{2}{|c|}{ Last extension } \\
\hline & & \multirow[t]{2}{*}{$\operatorname{Tm}^{\circ} \mathrm{C}$} & \multirow[t]{2}{*}{ Min } & \multicolumn{2}{|c|}{ Denaturation } & \multicolumn{2}{|c|}{ Annealing } & \multicolumn{2}{|c|}{ Extension } & \multirow[t]{2}{*}{$\mathrm{Tm}^{\circ} \mathrm{C}$} & \multirow[t]{2}{*}{ Min } \\
\hline & & & & $\mathrm{Tm}^{\circ} \mathrm{C}$ & Min & $\mathrm{Tm}^{\circ} \mathrm{C}$ & Min & $\operatorname{Tm}^{\circ} \mathrm{C}$ & Min & & \\
\hline \multirow[t]{4}{*}{ rs6265 } & $\mathrm{FO}$ & $94^{\circ} \mathrm{C}$ & $7 \mathrm{~min}$ & $94^{\circ} \mathrm{C}$ & $30 \mathrm{~s}$ & 61.5 & $25 \mathrm{~s}$ & $72^{\circ} \mathrm{C}$ & $45 \mathrm{~s}$ & $72^{\circ} \mathrm{C}$ & $7 \mathrm{~min}$ \\
\hline & $\mathrm{RO}$ & & & & & & & & & & \\
\hline & $\mathrm{FI}(\mathrm{c})$ & & & & & & & & & & \\
\hline & $\mathrm{RI}(\mathrm{t})$ & & & & & & & & & & \\
\hline \multirow[t]{4}{*}{ rs713729 } & $\mathrm{FO}$ & & & & & 61 & $30 \mathrm{~s}$ & & $30 \mathrm{~s}$ & & $5 \mathrm{~min}$ \\
\hline & $\mathrm{RO}$ & & & & & & & & & & \\
\hline & $\mathrm{FI}(\mathrm{a})$ & & & & & & & & & & \\
\hline & $\mathrm{RI}(\mathrm{t})$ & & & & & & & & & & \\
\hline \multirow[t]{4}{*}{ rs2076369 } & $\mathrm{FO}$ & & & & & 64 & $25 \mathrm{~s}$ & & $30 \mathrm{~s}$ & & $5 \mathrm{~min}$ \\
\hline & $\mathrm{RI}(\mathrm{t})$ & & & & & & & & & & \\
\hline & $\mathrm{Fl}(\mathrm{g})$ & & & & & 67 & $30 \mathrm{~s}$ & & & & \\
\hline & $\mathrm{RO}$ & & & & & & & & & & \\
\hline
\end{tabular}

FO: Forward outer primer; FI: Forward inner primer; RI: Reverse inner primer; RO: Reverse outer primer; TM: Temperature; Min: Minute; S: Seconds; ${ }^{\circ} \mathrm{C}:$ Centigrade; ARMS-PCR: Amplification refractory mutation system-polymerase chain reaction; SNP: Single nucleotide polymorphism

interaction effect of the SNPs, located on the same haplotype. $P$-value $=0<0.05$ was considered to be statistically significant. SPSS 20.0 (Inc., Chicago, IL, USA), PHASE program as well as SNP Analyser 2 software were used for further statistical analysis [29].

\section{Haplotype analysis}

Haplotypes were generated and assembled from the genotyped data by PHASE program, to reconstruct haplotypes, and SNP Analyzer 2 software [29, 30]. In the present study, $P$-values $_{\text {of less than }} 0.05$ were considered to be statistically significant. Moreover, Bonferroni correction was also used to account for multiple testing; thus, a twotailed $P_{\text {-value }}<0.016(=0.05 / 3 \mathrm{SNPs})$ was considered to be statistically significant in the present study.

\section{Results}

Identification of single nucleotide polymorphisms (SNPs) and association studies

There were no significant associations between BDNFrs6265 and the risk of methamphetamine dependence (SUD). On the contrary, a significant association was observed between two SNPs and the risk of methamphetamine abuse including PICK1-rs713729 (OR 1.38 (CI $1.08-1.52 ; P_{-}$value 0.004$)$ in multiplicative and dominant models, and PICK1-rs2076369 (OR 1.31 (CI 1.10-1.56; $\left.P_{\text {-value }} 0.002\right)$ in multiplicative, dominant and co-dominant models (Table 6). Moreover, haplotype analysis showed that specific haplotypes related to these SNPs were associated with methamphetamine dependence (SUD). In this line, analysis of PICK1-rs713729 and PICK1-rs2076369 haplotypes in our population showed that the haplotype AG (OR 2.50 (CI $1.50-4.16 ; P$-value $_{\text {val }}$ $0.0002)$ in dominant, recessive and co-dominant models and haplotype TT (OR 0.67 (CI 0.50-0.91; $P$-value 0.009$)$ in dominant model and co-dominant model had a significant association with the risk of methamphetamine dependence SUD) (Table 7).

Distribution of single nucleotide polymorphisms (SNPs)

The frequencies of the genotypes with high-quality genotype call were as follows: PICK1-rs713729 "TT" 174 (77.67\%), "AT" 33 (14.73\%), and "AA" 17 (7.58\%) among cases and "TT" 168 (87.95\%), "AT" 17 (8.90\%) and "AA" 6 (3.14\%) among controls; PICK1-rs2076369 "GG" 117 (52.23\%), "GT" 80 (35.71\%) and "TT" 27 (12.05\%) among cases and 70 (36.08\%), 100 (51.54\%), 24 (12.37\%) and among controls, respectively. Moreover, BDNFrs6265 genotype frequencies were: "CC" 161 (72.52\%), "CT" 55 (24.77\%) and "TT" 6 (2.70\%) among cases and 142 (73.57\%), 48 (24.87\%) and 3 (1.55\%) among controls, respectively. Table 7 shows the conferred risk by each haplotype. In this study, two haplotypes, AG and TT were significantly different between the normal and methamphetamine dependence (SUD) individuals. The prevalence of TT haplotype in the case group (27\%) was lower than that of the normal individuals (34\%), and the frequency of the AG haplotype in the methamphetamine dependence (SUD) individuals was higher (12\%) than that $(3 \%)$ of the normal individuals (Additional file 1: Table 1). We also examined whether the three SNPs were in LD. In this line, there was no strong LD between these SNPs (Additional file 2: Table 1). 
Table 6 Analysis based on different genetic models

\begin{tabular}{|c|c|c|c|c|c|c|c|}
\hline SNP number & Gene & Position & Genetic models & OR & $95 \% \mathrm{Cl}$ & $P_{\text {-value }}{ }^{*}$ & $\begin{array}{l}\text { Bonferroni } \\
\text { correction } \\
\mathrm{P}_{\text {-value }}\end{array}$ \\
\hline \multirow[t]{4}{*}{ rs713729 } & PICK1 & $22: 38,059,462$ & Multiplicative & 2.12 & $1.34-3.36$ & 0.001 & 0.003 \\
\hline & & & Dominant & 2.08 & $1.21-3.57$ & 0.007 & 0.020 \\
\hline & & & Recessive & 2.51 & $0.97-6.52$ & 0.05 & 0.149 \\
\hline & & & Co-dominant & 2.71 & $1.04-7.06$ & 0.02 & 0.061 \\
\hline \multirow[t]{4}{*}{ rs2076369 } & PICK1 & $22: 38,067,645$ & Multiplicative & 0.68 & $0.05-0.91$ & 0.009 & 0.028 \\
\hline & & & Dominant & 0.51 & $0.34-0.76$ & 0.0008 & 0.003 \\
\hline & & & Recessive & 0.92 & $0.51-1.67$ & 0.806 & - \\
\hline & & & Co-dominant & 0.64 & $0.34-1.21$ & 0.003 & 0.008 \\
\hline \multirow[t]{4}{*}{ rs6265 } & $B D N F$ & $11: 27,658,369$ & Multiplicative & 1.09 & $0.74-1.61$ & 0.65 & - \\
\hline & & & Dominant & 1.05 & $0.68-1.63$ & 0.81 & - \\
\hline & & & Recessive & 1.75 & $0.43-7.13$ & 0.64 & - \\
\hline & & & Co-dominant & 1.76 & $0.43-7.18$ & 0.89 & - \\
\hline
\end{tabular}

PICK1: Protein interacting with C-kinase-1; BDNF: Brain-derived neurotrophic factor; SNP: Single nucleotide polymorphism. OR: Odds ratio; Cl: Confidence interval; $P_{\text {-values }}$ were obtained from Chi-square tests; ${ }^{*}$ Significant of $P_{\text {-value }}<0.05$; The association between methamphetamine, risk factors and alleles/genotypes was evaluated by binary logistic regression, estimating ORs and also Cls. Note: Significant $P_{\text {-value }}$ in bold; Bonferroni corrected $P_{\text {-value }}$ is 0.016

Table 7 Haplotype analysis based on different genetic models

\begin{tabular}{|c|c|c|c|c|c|}
\hline Genetic models & Haplotype & $P_{\text {-value }}{ }^{*}$ & OR & Lower Cl & Higher $\mathrm{Cl}$ \\
\hline \multirow[t]{4}{*}{ Multiplicative } & $\mathrm{H} 3$ & 0.0002 & 2.5 & 1.502 & 4.161 \\
\hline & $\mathrm{H} 2$ & 0.009 & 0.678 & 0.505 & 0.91 \\
\hline & $\mathrm{H} 1$ & 0.742 & 1.047 & 0.794 & 1.382 \\
\hline & $\mathrm{H} 4$ & 0.745 & 0.84 & 0.292 & 2.416 \\
\hline \multirow[t]{4}{*}{ Dominant } & $\mathrm{H} 2$ & 0.001 & 0.532 & 0.358 & 0.79 \\
\hline & $\mathrm{H} 3$ & 0.007 & 2.123 & 1.217 & 3.704 \\
\hline & $\mathrm{H} 1$ & 0.735 & 0.924 & 0.582 & 1.466 \\
\hline & $\mathrm{H} 4$ & 0.762 & 0.838 & 0.266 & 2.643 \\
\hline \multirow[t]{4}{*}{ Recessive } & $\mathrm{H} 3$ & 0.003 & 11.569 & 1.499 & 89.293 \\
\hline & $\mathrm{H} 1$ & 0.436 & 1.175 & 0.782 & 1.766 \\
\hline & $\mathrm{H} 4$ & 0.555 & 0.842 & 0.052 & 13.549 \\
\hline & $\mathrm{H} 2$ & 0.651 & 0.867 & 0.466 & 1.611 \\
\hline \multirow[t]{4}{*}{ Co-dominant } & $\mathrm{H} 3$ & 0.004 & 12.331 & 1.595 & 95.316 \\
\hline & $\mathrm{H} 2$ & 0.006 & 0.627 & 0.326 & 1.206 \\
\hline & $\mathrm{H} 1$ & 0.571 & 1.044 & 0.620 & 1.757 \\
\hline & $\mathrm{H} 4$ & 0.840 & 0.838 & 0.052 & 13.492 \\
\hline
\end{tabular}

H1: TG; H2: TT; H3: AT; H4: AG; OR: Odds ratio; Cl: Confidence interval; $P_{\text {-values }}$ were obtained from Chi-square tests. * Significant of $P_{\text {-value }}<0.05$; Significant $P$-value in bold

\section{Discussion}

The SUD is a persistent relapsing disorder with harmful consequences [31]. In this respect, the brain reward system such as mesocortical dopamine system is the common feature of this disorder [32, 33]. Furthermore, abnormal dopamine and glutamate systems are associated with the pathophysiology of SUD and dependency. However, the development of drug dependency is affected via factors, such as pharmacological effects on mental status, environmental and individual factors, such as genetics. In this respect, genetic factors are suggested to have a greater effect on drug dependency. It was shown that drugs abuse and addiction cause dopamine and opioid peptides to be released into the ventral striatum, which causes "high" sensation in abusers [33, 34].

The use of methamphetamine has become a serious health concern in Iranian methadone dependent patients $[24,35]$. In Iran, it is used to improve sexual performance and promote physical energy due to its stimulating effects [36]. It is shown that methamphetamine abuse has surged from 3.9\% amongst both genders in 2007 to $60.3 \%$ for men in 2014 and $89.5 \%$ for women in 2015-2016. Remarkably, the frequency of methamphetamine dependence amongst female methadone dependent patients in the Iranian population was higher. This dependency has been linked to multiple health issues in the social and health contexts of both genders, particularly women [35].

Showing a possible association between PICK1rs 713729 and PICK1-rs2076369 in the PICK1 gene promoter with methamphetamine dependence were the key findings of the present study. Consistent with our study, Matsuzawa et al. showed that PICK1-rs713729 and PICK1-rs2076369 were significantly associated with methamphetamine abuse in a Japanese population (Table 8). Additionally, they revealed that PICK1rs713729 was linked to those with spontaneous relapse of psychosis [16]. Moreover, PICK1 gene was reported as the beginning of methamphetamine addiction, worse 
Table 8 The association studies regarding methamphetamine and BDNF/PICK1 gene polymorphisms in the methamphetamine abusers and controls

\begin{tabular}{|c|c|c|c|c|c|}
\hline \multirow[t]{2}{*}{ Gene-SNP } & \multirow[t]{2}{*}{ Ethnicity } & \multicolumn{2}{|c|}{ Sample size } & \multirow[t]{2}{*}{ Result } & \multirow[t]{2}{*}{ Refs } \\
\hline & & Meth & Normal & & \\
\hline BDNF-Val66Met & Chinese & 200 & 219 & $\begin{array}{l}\text { No significant differences in genotype and allele. The Met } \\
\text { allele was associated with earlier age onset of METH use }\end{array}$ & [52] \\
\hline BDNF-rs16917204, rs16917234, rs2030324 & Chinese & 200 & 219 & $\begin{array}{l}\text { No significant differences in genotype and allele distribu- } \\
\text { tions }\end{array}$ & {$[53]$} \\
\hline BDNF-Val66Met & Taiwanese & 103 & 200 & $\begin{array}{l}\text { Significant differences in BDNF Val66Met genotype distri- } \\
\text { bution }\end{array}$ & {$[21]$} \\
\hline BDNF-Val66Met (rs6265) & Thai & 100 & 102 & $\begin{array}{l}\text { Significant differences in the distribution of rs } 6265 \text { geno- } \\
\text { type } \\
\text { A lower frequency of GG genotype associated with METH- } \\
\text { induced psychosis }\end{array}$ & {$[20]$} \\
\hline BDNF promoter methylation & Chinese & 30 & 52 & $\begin{array}{l}\text { BDNF promoter methylation is associated with drug addic- } \\
\text { tion }\end{array}$ & {$[54]$} \\
\hline BDNF-Val66Met & Chinese & 194 & 378 & $\begin{array}{l}\text { No significant differences in genotype and allele distribu- } \\
\text { tions } \\
\text { A significant positive correlation between serum BDNF and } \\
\text { the delayed memory index score }\end{array}$ & {$[55]$} \\
\hline BDNF-Val66Met & Japanese & 189 & 202 & $\begin{array}{l}\text { No significant differences were found in the frequency of } \\
\text { the genotype or allele }\end{array}$ & {$[56]$} \\
\hline \multirow[t]{5}{*}{ BDNF-Val66Met } & Chinese & 24 & 45 & \multirow{5}{*}{$\begin{array}{l}\text { A significant distribution of the BDNF Val66Met genotype } \\
\text { with METH dependence and METH psychosis in Chinese }\end{array}$} & \multirow[t]{5}{*}[22]{} \\
\hline & Malay & 59 & 51 & & \\
\hline & Kadazan-Dusun & 50 & 30 & & \\
\hline & Bajau & 53 & 28 & & \\
\hline & Total & 186 & 154 & & \\
\hline BDNF-Val66Met & Caucasian & 60 & None & $\begin{array}{l}\text { Significantly more pretreatment days with METH use in } \\
\text { females than males } \\
\text { A significant association between females with Val/Nal } \\
\text { genotype and METH use }\end{array}$ & {$[57]$} \\
\hline PICK1- s737622, rs3026682, rs713729, rs2076369 & Japanese & 208 & 218 & $\begin{array}{l}\text { A significantly association between: } \\
\text {-rs713729 and METH abusers } \\
\text {-rs713729 and rs2076369 with spontaneous relapse of } \\
\text { psychosis }\end{array}$ & {$[16]$} \\
\hline
\end{tabular}

SNP: Single nucleotide polymorphism; PICK1: Protein that interact with C-kinase-1; BDNF: Brain-derived neurotrophic factor; Val66Met (also called rs6265): Met: Methionine and Val: Valine; METH: Methamphetamine; Ref: References

prognosis as well as spontaneous relapse [37]. PICK1 is involved in the targeting and localization of synaptic membranes proteins and also in the surface of dopamine transporter clustering on the cell surface $[18,38]$. This clustering leads to an increase of dopamine transporter uptake activity. Thus, PICK1 expression levels can alter the role of the dopamine transporter and can affect the pathogenesis of methamphetamine abuse/ dependency [16]. Moreover, the interactions of PICK1 with $\alpha$-amino-3-hydroxy-5-methyl-4-isoxazole propionate (AMPA) receptors, metabotropic glutamate receptors and $\mathrm{D}$-serine synthesizing enzyme have been shown and might be implicated in the pathogenesis of drug-related disorders [39-42]. Further studies are still required to show the direct association of these proteins in the pathogenesis of methamphetamine abuse.

Based on previous studies, it was reported that gene variations, which are associated with glutamatergic and serotonin systems explain differences in SUD and/ or dependency risk between individuals. It is indicated that glutamate-related genes influence the risk of SUD and/or dependency. The glutamate receptor genes were suggested to interact with BDNF by BDNF- tropomyosin kinase $B(\operatorname{TrK} B)$ transduction signaling cascade. BDNF is a neurotrophic factor, which is involved in the expansion, maintenance and survival of dopaminergic neurons in CNS [43].

In the present study, no association was found between $B D N F-r s 6265$ and the risk of methamphetamine dependence (SUD) in our population. This finding is consistent with the result of methamphetamine dependent male Caucasian individuals, which showed no association in 193 non-psychotic males (117 methamphetaminedependent cases and 76 controls) [44]. However, Cheng et al. showed that there was an association between methamphetamine-dependency and BDNF gene in 103 
methamphetamine abusers and 122 normal controls. They noted that the lower 66Met carriers were linked to substance abuse [21]. Furthermore, Sim et al. described an increase in a Chinese subgroup of Malaysian methamphetamine-dependent subjects $(n=24)$, which was not found among other Malaysian ethnic groups [22]. The various results for this SNP might be due to different sample sizes and also different ethnicities as well as genetic diversity (Table 8 ). It is indicated that ethnic differences can affect the frequency of BDNF Val66Met [45, 46].

Long-term methamphetamine-induced brain changes are significantly dependent on BDNF genetic variation [47]. Val66Met might enhance the risk of suicide behavior [45]. Moreover, BDNF variations might be involved in methamphetamine withdrawal. BDNF levels, equal or less than $1,251.0 \mathrm{pg} / \mathrm{ml}$ has been stated to be linked to depression symptoms during methamphetamine withdrawal [48]. BDNF Val66Met had an important effect on the Treatment Effectiveness Score (TES), methamphetamine-negative urine drug screens during treatment, which was higher among Val/Val Caucasian carriers [49]. Interestingly, there were more pretreatment days with methamphetamine use in females with Val/Val genotype than males [10]. Estrogen improves BDNF expression, which has implications on the release of striatal dopamine caused by methamphetamine and protects against neurotoxicity caused by methamphetamine [50, 51]. Thus, females can be able to use methamphetamine more frequently [10].

Furthermore, there was no association between PICK1 and $B D N F$ gene polymorphisms in our study. That may be attributed to the different positions of the gene polymorphisms on different chromosomes [PICK1 (22q13.1) and BDNF (11p13-15)].

There were some limitations in our study. We did not investigate all the SNPs in these genes. Although, the sample size was large enough to detect an association between these SNPs and SUD in comparison with previous studies, larger sample size would strengthen the results. We therefore recommend further replication studies with larger sample size in order to validate and explain this association with conclusive findings.

\section{Conclusions}

Collectively, the variation in the PICK1 gene was associated with methamphetamine dependence (SUD), reflecting the underlying biological mechanisms, which can make a bridge between pathways and methamphetamine dependence (SUD). Our findings suggest that the PICK1 gene might be involved in susceptibility to SUD in our population. These findings can be helpful in rehabilitation programs and psychoeducation for those who have substance dependency. In this case, potential genetic predictors can be used for individuals susceptible to SUD. All in all, understanding genetic variations might help to understand the biological mechanisms of progression, and suppression of methamphetamine. In addition, our findings provide the basis for future genetic research on the use of methamphetamine dependency and related neurological side effects.

\section{Supplementary information}

is available for this paper at https://doi.org/10.1186/s12920-021-00873-7.

Additional file 1. Haplotype frequencies in population.

Additional file 2. LD map and LD block.

\section{Abbreviations}

AKT1: V-akt murine thymoma viral oncogene homolog 1; AMPA: a-Amino-3hydroxy-5-methyl-4-isoxazole propionate; ARMS-PCR: Amplification refractory mutation system-polymerase chain reaction; ARRB2: Arrestin beta 2; BDNF: Brain-derived neurotrophic factor; Cls: Confidence intervals; CNS: Central nervous system; COMT: Catechol-O-methyltransferase; CYP2D6: Cytochrome P450 2D6; DRD4: Dopamine receptor D4; EDTA: Ethylene diamine tetra acetic acid; GABRA1: Gamma-aminobutyric acid type A receptor subunit alpha1; GABRG2: Gamma-aminobutyric acid receptor subunit gamma-2; GLYT1: Glycine transporter-1; GSTM1: Glutathione S-transferase mu 1; GSTP1: Glutathione S-transferase P1; HWE: Hardy-Weinberg equilibrium; LD: Linkage disequilibrium; MAF: Minor allele frequency; Nm: Nanometres; ORs: Odds ratios; PDYN: Prodynorphin; PICK1: Protein interacting with C kinase; SLC22A3: Solute carrier family 22 member 3; SNP: Single nucleotide polymorphism; SUD: Substance use disorder; TES: Treatment Effectiveness Score; TrKB: BDNF-tropomyosin kinase B; WASP: Web-based allele-specific primer designing tool.

\section{Acknowledgements}

Authors wish to thank Mashhad University of Medical Sciences.

\section{Authors' contributions}

AT: Conception and design, sample and data collection, extraction of genomic DNA, genotyping, data analysis and writing the manuscript; MA1: Sample and data collection, extraction of genomic DNA, genotyping and data analysis; MA2: Sample and data collection, extraction of genomic DNA and genotyping; SA: Sample and data collection, extraction of genomic DNA, and genome genotyping; SSKh: Performing required interviews, completing questionnaires, sample and data collection and analysis; ANB: Sample and data collection, extraction of genomic DNA, and data analysis; FA: Sample and data collection, and data analysis; MA3: Sample and data collection, extraction of genomic DNA, and data analysis; AS: Data analysis and critical review; PH: Conception and design, clinical diagnosis, approval of the manuscript; AP: Conception and design, supervision of the project, revising and approval of the manuscript. All authors read and approved the final manuscript.

\section{Funding}

This study was financially supported by the Mashhad University of Medical Sciences (Grant Number: 931681).

\section{Availability of data and materials}

The datasets created during the current study are not publicly accessible due to the possibility of compromising the privacy of individuals. According to the written approval forms accepted by the Ethics Committee of the Mashhad University of Medical Sciences (MUMS), the data will only be available to researchers within project. The data would be available upon request from the corresponding authors (according to the MUMS rules and regulations). 


\section{Ethics approval and consent to participate}

The study was approved by the Mashhad University of Medical Science Ethics Committee (ethical approval code: IR.MUMS.fm. REC.1394.421).In this context, written informed consent has been obtained from all individuals.

\section{Consent to publish}

All individuals whose data are described have signed a written informed consent form.

\section{Competing interests}

All authors have read the manuscript and declared that they have no competing interest.

\begin{abstract}
Author details
1 Pharmaceutical Sciences Research Center, Shiraz University of Medical Sciences, Shiraz, Iran. ${ }^{2}$ Department of Medical Genetics and Molecular Medicine, Faculty of Medicine, Mashhad University of Medical Sciences, Mashhad, Iran. ${ }^{3}$ Ibn-E-Sina and Dr Hejazi Psychiatry Hospital, University of Medical Sciences, Mashhad, Iran. ${ }^{4}$ Department of Medical Genetics, Ayatollah Madani Hospital, Gonabad University of Medical Sciences, Gonabad, Iran. ${ }^{5}$ Islamic Azad University Torbat-e Jam Branch, Torbat-e-Jam, Iran. ${ }^{6}$ Epilepsy Research Center, Shiraz University of Medical Sciences, Shiraz, Iran. ${ }^{7}$ Department of Medical Biotechnology, School of Advanced Medical Sciences and Technologies, Shiraz University of Medical Sciences, Shiraz, Iran. ${ }^{8}$ Medical Genetics Research Centre, Mashhad University of Medical Sciences, Mashhad, Iran. ${ }^{9}$ Psychiatry and Behavioral Sciences Research Center, Mashhad University of Medical Sciences, Mashhad, Iran. ${ }^{10}$ Division of Applied Medicine, Faculty of Medicine, University of Aberdeen, Foresterhill, Aberdeen, UK.
\end{abstract}

Received: 10 January 2021 Accepted: 12 January 2021

Published online: 26 January 2021

\section{References}

1. Kendler KS, Karkowski LM, Neale MC, Prescott CA. Illicit psychoactive substance use, heavy use, abuse, and dependence in a US population-based sample of male twins. Arch Gen Psychiatry. 2000;57(3):261-9.

2. Uhl GR, Liu QR, Naiman D. Substance abuse vulnerability loci: converging genome scanning data. Trends Genet. 2002;18(8):420-5.

3. Goldman D, Oroszi G, Ducci F. The genetics of addictions: uncovering the genes. Nat Rev Genet. 2005;6(7):521-32.

4. Volkow N, Li TK. The neuroscience of addiction. Nat Neurosci. 2005;8(11):1429-30

5. Kerdsan W, Thanoi S, Nudmamud-Thanoi S. Changes in the neuronal glutamate transporter EAAT3 in rat brain after exposure to methamphetamine. Basic Clin Pharmacol Toxicol. 2012;111(4):275-8.

6. Joyce JN, Renish L, Osredkar T, Walro JM, Kucera J, Dluzen DE. Methamphetamine-induced loss of striatal dopamine innervation in BDNF heterozygote mice does not further reduce D3 receptor concentrations. Synapse. 2004;52(1):11-9.

7. Mark KA, Soghomonian JJ, Yamamoto BK. High-dose methamphetamine acutely activates the striatonigral pathway to increase striatal glutamate and mediate long-term dopamine toxicity. J Neurosc. 2004;24(50):11449-56.

8. Yamamoto BK, Bankson MG. Amphetamine neurotoxicity: cause and consequence of oxidative stress. Crit Rev Neurobiol. 2005;17(2):87-117.

9. Fumagalli F, Gainetdinov RR, Valenzano KJ, Caron MG. Role of dopamine transporter in methamphetamine-induced neurotoxicity: evidence from mice lacking the transporter. J Neurosci. 1998;18(13):4861-9.

10. Blakely RD, Bauman AL. Biogenic amine transporters: regulation in flux. Curr Opin Neurobiol. 2000;10(3):328-36.

11. Robinson MB. Regulated trafficking of neurotransmitter transporters: common notes but different melodies. J Neurochem. 2002;80(1):1-11.

12. Volkow ND, Chang L, Wang GJ, Fowler JS, Leonido-Yee M, Franceschi D, Sedler MJ, Gatley SJ, Hitzemann R, Ding YS, et al. Association of dopamine transporter reduction with psychomotor impairment in methamphetamine abusers. Am J Psychiatry. 2001;158(3):377-82.

13. Sekine $Y$, Iyo M, Ouchi Y, Matsunaga T, Tsukada H, Okada H, Yoshikawa E, Futatsubashi M, Takei N, Mori N. Methamphetamine-related psychiatric symptoms and reduced brain dopamine transporters studied with PET. Am J Psychiatry. 2001;158(8):1206-14.

14. Ujike H, Harano M, Inada T, Yamada M, Komiyama T, Sekine Y, Sora I, Iyo M, Katsu T, Nomura A, et al. Nine- or fewer repeat alleles in VNTR polymorphism of the dopamine transporter gene is a strong risk factor for prolonged methamphetamine psychosis. Pharmacogenomics J. 2003;3(4):242-7.

15. Bousman CA, Glatt SJ, Everall IP, Tsuang MT. Genetic association studies of methamphetamine use disorders: a systematic review and synthesis. Am J Med Genet B Neuropsychiatr Genet. 2009;150B(8):1025-49.

16. Matsuzawa D, Hashimoto K, Miyatake R, Shirayama Y, Shimizu E, Maeda K, Suzuki Y, Mashimo Y, Sekine Y, Inada T, et al. Identification of functional polymorphisms in the promoter region of the human PICK1 gene and their association with methamphetamine psychosis. Am J Psychiatry. 2007;164(7):1105-14.

17. Stober G, Meyer J, Nanda I, Wienker TF, Saar K, Knapp M, Jatzke S, Schmid $\mathrm{M}$, Lesch KP, Beckmann H. Linkage and family-based association study of schizophrenia and the synapsin III locus that maps to chromosome 22q13. Am J Med Genet. 2000;96(3):392-7.

18. Deken SL, Beckman ML, Quick MW. PICKing on transporters. Trends Neurosci. 2001;24(11):623-5.

19. Haerian BS. BDNF rs6265 polymorphism and drug addiction: a systematic review and meta-analysis. Pharmacogenomics. 2013;14(16):2055-65.

20. lamjan SA, Thanoi S, Watiktinkorn P, Nudmamud-Thanoi S, Reynolds GP. BDNF (Val66Met) genetic polymorphism is associated with vulnerability for methamphetamine dependence. Pharmacogenomics. 2015;16(14):1541-5.

21. Cheng CY, Hong CJ, Yu YW, Chen TJ, Wu HC, Tsai SJ. Brain-derived neurotrophic factor (Val66Met) genetic polymorphism is associated with substance abuse in males. Brain Res Mol Brain Res. 2005;140(1-2):86-90.

22. Sim MS, Mohamed Z, Hatim A, Rajagopal VL, Habil MH. Association of brain-derived neurotrophic factor (Val66Met) genetic polymorphism with methamphetamine dependence in a Malaysian population. Brain Res. 2010;1357:91-6.

23. Bolanos CA, Nestler EJ. Neurotrophic mechanisms in drug addiction. Neuromolecular Med. 2004;5(1):69-83.

24. Alam-mehrjerdi Z, Mokri A, Dolan K. Methamphetamine use and treatment in Iran: a systematic review from the most populated Persian Gulf country. Asian J Psychiatr. 2015;16:17-25.

25. Mclellan AT. Substance misuse and substance use disorders: Why do they matter in healthcare? Trans Am Climatol Assoc. 2017;128:112.

26. Hasin DS, O'Brien CP, Auriacombe M, Borges G, Bucholz K, Budney A, Compton WM, Crowley T, Ling W, Petry NM. DSM-5 criteria for substance use disorders: recommendations and rationale. Am J Psychiatry. 2013;170(8):834-51.

27. Mardan-Nik M, Saffar Soflaei S, Biabangard-Zak A, Asghari M, Saljoughian S, Tajbakhsh A, Meshkat Z, Ferns GA, Pasdar A, Ghayour-Mobarhan M. A method for improving the efficiency of DNA extraction from clotted blood samples. J Clin Lab Anal. 2019;33(6):e22892.

28. Liu J, Huang S, Sun M, Liu S, Liu Y, Wang W, Zhang X, Wang H, Hua W. An improved allele-specific PCR primer design method for SNP marker analysis and its application. Plant Methods. 2012;8(1):34.

29. Yoo J, Lee Y, Kim Y, Rha SY, Kim Y: SNPAnalyzer 2.0: A web-based integrated workbench for linkage disequilibrium analysis and association analysis. BMC Bioinformatics 2008, 9(1):290.

30. Stephens M, Smith NJ, Donnelly P. A new statistical method for haplotype reconstruction from population data. Am J Hum Genet. 2001;68(4):978-89.

31. Association AP: Diagnostic and statistical manual of mental disorders $\left(\right.$ DSM-5 $\left.{ }^{\circledR}\right)$ : American Psychiatric Pub; 2013.

32. Koob GF, Bloom FE. Cellular and molecular mechanisms of drug dependence. Science. 1988;242(4879):715-23.

33. Volkow ND, Fowler JS, Wang GJ. The addicted human brain: insights from imaging studies. J Clin Invest. 2003;111(10):1444-51.

34. Volkow ND, Wang GJ, Telang F, Fowler JS, Logan J, Jayne M, Ma Y, Pradhan $\mathrm{K}$, Wong $\mathrm{C}$. Profound decreases in dopamine release in striatum in detoxified alcoholics: possible orbitofrontal involvement. J Neurosci. 2007;27(46):12700-6.

35. Alammehrjerdi Z, Ezard N, Dolan K. Methamphetamine dependence in methadone treatment services in Iran: the first literature review of a new health concern. Asian J Psychiatr. 2018;31:49-55. 
36. Shariatirad S, Maarefvand M, Ekhtiari H. Methamphetamine use and methadone maintenance treatment: an emerging problem in the drug addiction treatment network in Iran. Int J Drug Policy. 2013;24(6):e115-116.

37. Ujike $\mathrm{H}$ : [Potential genetic predictors for individual vulnerability to substance dependence]. Nihon shinkei seishin yakurigaku zasshi = Japanese journal of psychopharmacology 2008, 28(1):11-17.

38. Torres GE, Yao WD, Mohn AR, Quan H, Kim KM, Levey Al, Staudinger J, Caron MG. Functional interaction between monoamine plasma membrane transporters and the synaptic PDZ domain-containing protein PICK1. Neuron. 2001;30(1):121-34

39. Hanley JG, Henley JM. PICK1 is a calcium-sensor for NMDA-induced AMPA receptor trafficking. EMBO J. 2005;24(18):3266-78.

40. Perroy J, El Far O, Bertaso F, Pin JP, Betz H, Bockaert J, Fagni L. PICK1 is required for the control of synaptic transmission by the metabotropic glutamate receptor 7. EMBO J. 2002;21(12):2990-9.

41. Fujii K, Maeda K, Hikida T, Mustafa AK, Balkissoon R, Xia J, Yamada T, Ozeki Y, Kawahara R, Okawa M, et al. Serine racemase binds to PICK1: potential relevance to schizophrenia. Molecular Psychiatry. 2006;11(2):150-7.

42. D'Ascenzo M, Podda MV, Grassi C. The role of D-serine as co-agonist of NMDA receptors in the nucleus accumbens: relevance to cocaine addiction. Front Synaptic Neurosci. 2014;6(16):16.

43. Li X, Wolf ME. Brain-derived neurotrophic factor rapidly increases AMPA receptor surface expression in rat nucleus accumbens. Eur J Neurosci. 2011;34(2):190-8.

44. Bousman CA, Glatt SJ, Cherner M, Atkinson JH, Grant I, Tsuang MT, Everall IP, Group H. Preliminary evidence of ethnic divergence in associations of putative genetic variants for methamphetamine dependence. Psychiatry Res. 2010;178(2):295-8.

45. González-Castro TB, Salas-Magaña M, Juárez-Rojop IE, López-Narváez ML, Tovilla-Zárate CA, Hernández-DíazY. Exploring the association between BDNF Val66Met polymorphism and suicidal behavior: Meta-analysis and systematic review. J Psychiatr Res. 2017:94:208-17.

46. Bousman CA, Glatt SJ, Cherner M, Atkinson JH, Grant I, Tsuang MT, Everall IP. Preliminary evidence of ethnic divergence in associations of putative genetic variants for methamphetamine dependence. Psychiatry Res. 2010;178(2):295-8.

47. Greening DW, Notaras M, Chen M, Xu R, Smith JD, Cheng L, Simpson RJ, Hill AF, van den Buuse M: Chronic methamphetamine interacts with BDNF Val66Met to remodel psychosis pathways in the mesocorticolimbic proteome. Molecular psychiatry 2019.
48. Ren W, Luan X, Zhang J, Gutteea P, Cai Y, Zhao J, Gu Y, Wu C, Su H, Tao $J$, et al. Brain-derived neurotrophic factor levels and depression during methamphetamine withdrawal. J Affect Disord. 2017;221:165-71.

49. Heinzerling KG, McCracken JT, Swanson A-N, Ray LA, Shoptaw SJ. COMT Val158Met, BDNF Val66Met, and OPRM1 Asn40Asp and methamphetamine dependence treatment response: preliminary investigation. J Clin Psychopharmacol. 2012;32(1):135-7.

50. Gajjar TM, Anderson LI, Dluzen DE. Acute effects of estrogen upon methamphetamine induced neurotoxicity of the nigrostriatal dopaminergic system. J Neural Transm (Vienna). 2003;110(11):1215-24.

51. Dluzen DE, McDermott JL. Neuroprotective role of estrogen upon methamphetamine and related neurotoxins within the nigrostriata dopaminergic system. Ann NY Acad Sci. 2000;914:112-26.

52. Su H, Tao J, Zhang J, Xie Y, Sun Y, Li L, Xu K, Han B, Lu Y, Sun H, et al. An association between BDNF Val66Met polymorphism and impulsivity in methamphetamine abusers. Neurosci Lett. 2014;582:16-20.

53. Su H, Tao J, Zhang J, Xie Y, Han B, Lu Y, Sun H, Wei Y, Wang Y, Zhang Y, et al. The analysis of BDNF gene polymorphism haplotypes and impulsivity in methamphetamine abusers. Compr Psychiatry. 2015;59:62-7.

54. Xu X, Ji H, Liu G, Wang Q, Liu H, Shen W, Li L, Xie X, Zhou W, Duan S. A significant association between BDNF promoter methylation and the risk of drug addiction. Gene. 2016;584(1):54-9.

55. Su H, Tao J, Zhang J, Xie Y, Wang Y, Zhang Y, Han B, Lu Y, Sun H, Wei Y, et al. The effects of BDNF Val66Met gene polymorphism on serum BDNF and cognitive function in methamphetamine-dependent patients and normal controls: a case-control study. J Clin Psychopharmacol. 2015:35(5):517-24.

56. Itoh K, Hashimoto K, Shimizu E, Sekine Y, Ozaki N, Inada T, Harano M, Iwata $\mathrm{N}$, Komiyama T, Yamada M et al: Association study between brain-derived neurotrophic factor gene polymorphisms and methamphetamine abusers in Japan. Am J Med Genet B Neuropsychiatr Genet 2005, 132b(1):70-73.

57. Heinzerling KG, Shoptaw S. Gender, brain-derived neurotrophic factor Val66Met, and frequency of methamphetamine use. Gend Med. 2012;9(2):112-20.

\section{Publisher's Note}

Springer Nature remains neutral with regard to jurisdictional claims in published maps and institutional affiliations.
Ready to submit your research? Choose BMC and benefit from:

- fast, convenient online submission

- thorough peer review by experienced researchers in your field

- rapid publication on acceptance

- support for research data, including large and complex data types

- gold Open Access which fosters wider collaboration and increased citations

- maximum visibility for your research: over 100M website views per year

At BMC, research is always in progress.

Learn more biomedcentral.com/submissions 